\title{
Activation of Pathogenesis-related Genes by the Rhizobacterium, Bacillus sp. JS, Which Induces Systemic Resistance in Tobacco Plants
}

\author{
Ji-Seong Kim ${ }^{1,3}$, Jeongeun Lee ${ }^{1,3}$, Chan-hui Lee ${ }^{2}$, Su Young Woo ${ }^{3}$, Hoduck Kang ${ }^{4}$, Sang-Gyu Seo ${ }^{3}$ and \\ Sun-Hyung Kim ${ }^{3 *}$ \\ ${ }^{1}$ Graduate School of Life and Environmental Sciences, University of Tsukuba, Ibaraki 305-8572, Japan \\ ${ }^{2}$ Graduate School of Biotechnology, Kyung Hee University, Yongin 446-701, Korea \\ ${ }^{3}$ Department of Environmental Horticulture, The University of Seoul, Seoul 130-743, Korea \\ ${ }^{4}$ Department of Biological and Environmental Science, Dongguk University, Seoul 100-715, Korea
}

(Received on November 25, 2014; Revised on January 5, 2015; Accepted on February 8, 2015)

Plant growth promoting rhizobacteria (PGPR) are known to confer disease resistance to plants. Bacillus sp. JS demonstrated antifungal activities against five fungal pathogens in in vitro assays. To verify whether the volatiles of Bacillus sp. JS confer disease resistance, tobacco leaves pre-treated with the volatiles were damaged by the fungal pathogen, Rhizoctonia solani and oomycete Phytophthora nicotianae. Pre-treated tobacco leaves had smaller lesion than the control plant leaves. In pathogenesis-related (PR) gene expression analysis, volatiles of Bacillus sp. JS caused the up-regulation of PR-2 encoding $\beta$-1,3-glucanase and acidic PR-3 encoding chitinase. Expression of acidic PR-4 encoding chitinase and acidic PR-9 encoding peroxidase increased gradually after exposure of the volatiles to Bacillus sp. JS. Basic PR-14 encoding lipid transfer protein was also increased. However, PR-1 genes, as markers of salicylic acid (SA) induced resistance, were not expressed. These results suggested that the volatiles of Bacillus sp. JS confer disease resistance against fungal and oomycete pathogens through PR genes expression.

Keywords : antifungal activities, disease resistance, plant growth promoting rhizobacteria

Plant disease can be defined as the series of invisible and visible responses of plant cells and tissues to a pathogenic organism or environmental factor that result in adverse changes in the form, function, or integrity of the plant, and which may lead to partial impairment or death of plant

*Corresponding author.

Phone) +82264902692 , FAX) +82264902684

E-mail)mongal@uos.ac.kr parts or the entire plant. Plant yield loss has been estimated as $36.5 \%$, with $14.1 \%$ caused by disease (Agrios, 2005). To control plant diseases, pesticides have been extensively employed. However, increased use of chemicals causes negative effects like pathogen resistance to chemicals, environmental problems, residue in food, elimination of useful microorganisms, and increased cost. Many efforts therefore have been focused on biological control.

Biocontrol using plant growth promoting rhizobacteria (PGPR) may be an alternative method for controlling plant diseases. Some PGPR have the ability to produce antifungal metabolites. For example, Pseudomonas fluorescens can biosynthesize pyrrolnitrin that inhibits Rhizoctonia spp, Fusarium spp, and other plant pathogenic fungi (Ligon et al., 2000). 2,4-diacetylphloroglucinol, pyoluteorin, and cyclic lipopeptides produced by several fluorescent $\mathrm{Pseu}$ domonas strains have antifungal activity (Defago, 1993; Nielsen et al., 2002; Sharifi-Tehrani et al., 1998). Hydrogen cyanide, oomycin A, phenazine, tensin, and tropolone are also produced by Pseudomonas spp. (Raaijmakers et al., 2002). Bacillus, Streptomyces, and Stenotrophomonas spp. produce antifungal metabolites, oligomycin A, kanosamine, zwittermicin A, and xanthobaccin (van Loon et al., 2006). Duijff et al. (1994) reported that Pseudomonas putida WCS358 suppresses fusarium wilt disease by producing siderophores as a competitor for iron.

Another alternative for controlling plant disease is the induction of resistance. Induced systemic resistance can be categorized as systemic acquired resistance (SAR) or induced systemic resistance (ISR). Systemic plant resistance induced by infection of virulent, avirulent, and nonpathogenic microorganisms represents SAR. SAR depends on the salicylic acid (SA) pathway, which is followed by PR gene expression (Ryals et al., 1996). Systemic plant resistance induced by PGPR represents ISR, and is believed to 
be regulated by jasmonic acid and ethylene.

ISR can protect plants against a wide range of pathogens (van Loon et al., 1998) through the activation of PR proteins like $\beta$-1,3-glucanases, chitinases, and peroxidases (Yedidia et al., 1999), the accumulation of phytoalexins, and formation of physical barriers such as callose and lignin (Whipps, 2001). However, distinguishing SAR from ISR with PGPR as inducer may not be obvious. Several PGPR like Bacillus and Pseudomonas induce SAR represented by PR-1a expression as a SA pathway marker, in addition to disease resistance (Park and Kloepper, 2000). In contrast, Pseudomonas fluorescens confers disease resistance through a SA-independent pathway (Pieterse et al., 1998). Studies of ISR have concentrated on a few species and were conducted by adding bacterial suspension to the plant rhizosphere followed by pathogen infection (van Loon et al., 1998). Evidence that bacterial volatiles can activate disease resistance has been presented in previous reports. Ryu et al. (2004) reported that the 2,3-butanediol volatile of Bacillus subtilis GB03 reduces disease.

In this study, we show that a diffusible chemical produced by Bacillus sp. JS has antifungal activity and that volatiles of Bacillus sp. JS induce the expression of several PR genes and confer disease resistance to Nicotiana tabacum.

Bacillus sp. strain JS and Escherichia coli strain DH5 $\alpha$ were streaked on nutrient agar (Difco, USA) and cultured at $28^{\circ} \mathrm{C}$ and $37^{\circ} \mathrm{C}$ for $14 \mathrm{~h}$, respectively. A single colony was transferred to $30 \mathrm{ml}$ of nutrient broth (Difco, USA) and grown on a reciprocating shaker $(110 \mathrm{rpm})$ at $28^{\circ} \mathrm{C}$ to a concentration of $1 \times 10^{7}$ colony forming units $(\mathrm{cfu}) / \mathrm{ml}$. Five soil borne pathogens - Rhizoctonia solani AG-1 (IB) KACC No. 40110, Phytophthora nicotianae KACC No. 40906, Sclerotinia sclerotiorum, Phytophthora capsici, and

Table 1. Primer sequences of pathogenesis-related (PR) genes in tobacco plants used for RT-PCR

\begin{tabular}{|c|c|c|c|}
\hline Name & Primer sequences & $\begin{array}{c}\text { Annealing } \\
\text { temperature }\left({ }^{\circ} \mathrm{C}\right)\end{array}$ & Accession number \\
\hline Acidic PRla & $\begin{array}{l}\text { 5'-AATATCCCACTCTTGCCG-3' } \\
\text { 5'-CCTGGAGGATCATAGTTG-3' }\end{array}$ & 50 & $\mathrm{X} 12485$ \\
\hline Acidic PRIb & $\begin{array}{l}\text { 5'-ATCTCACTCTTCTCATGC-3' } \\
\text { 5'-TACCTGGAGGATCATAGT-3' }\end{array}$ & 50 & X12486 \\
\hline Acidic PR2 & $\begin{array}{l}\text { 5'-ACCATCAGATCAAGATGT-3' } \\
\text { 5'-TGGCTAAGAGTGGAAGGT-3' }\end{array}$ & 50 & DQ206348 \\
\hline Basic PR2 & $\begin{array}{l}\text { 5'-CAGCCCTGTCACTGGCACAT-3' } \\
\text { 5'-CCCTACAGATGCCCCTCCTG-3' }\end{array}$ & 60 & M59442 \\
\hline Acidic PR3 (PR-P) & $\begin{array}{l}\text { 5'-GGTAGTTGGACTCCGTCCGC-3' } \\
\text { 5'-TCGTTTTCACTCGAAGCACCA-3' }\end{array}$ & 60 & M29869 \\
\hline Acidic PR3 (PR-Q) & $\begin{array}{l}\text { 5'-ATCGGTCGTTGGACTCCGTC-3' } \\
\text { 5'-GCCTCATCACTTAAAAGCGCC-3' }\end{array}$ & 60 & M29868 \\
\hline Basic PR3 & $\begin{array}{l}\text { 5'-ATGAGGCTTTGTAAATTC-3' } \\
\text { 5'-AGTCGCCGGGGCTACCTTG-3' }\end{array}$ & 50 & S44869 \\
\hline Acidic PR4 & $\begin{array}{l}\text { 5'-TGCTTTCTGCGCTACTTGGG-3' } \\
\text { 5'-GCCCCTTCTTATTCTAAACGGC-3' }\end{array}$ & 60 & X58546 \\
\hline Basic PR4 & $\begin{array}{l}\text { 5'-ATGGTTGGAACTTCCGGA-3' } \\
\text { 5'-TCCTGATCTCTCTGCTAC-3' }\end{array}$ & 50 & AF154635 \\
\hline Basic PR5 & $\begin{array}{l}\text { 5'-ATGAGAAAGACCCACGTC-3' } \\
\text { 5'-ATGCCTTCTTTGCAGCAG-3' }\end{array}$ & 50 & AF154636 \\
\hline Neutral PR5 & $\begin{array}{l}\text { 5'-TAGTCGGGCCAAAAGACATAGG-3' } \\
\text { 5'-GAGGTCAAAGTTGGTGGTTCTG-3' }\end{array}$ & 60 & AB121784 \\
\hline Acidic PR9 (NtPrx9) & $\begin{array}{l}\text { 5'-TGCACACACATTTGGAAGAGCA-3' } \\
\text { 5'-TTGGAATTGCCATTTCAGCACA-3' }\end{array}$ & 60 & J02979 \\
\hline Basic PR14 (LTP1) & $\begin{array}{l}\text { 5'-TGGTGTGCATGGCAGCAGTA-3' } \\
\text { 5'-TCCATCTTCTCCAAGAACGCA-3' }\end{array}$ & 60 & AY562132 \\
\hline Actin & $\begin{array}{l}\text { 5'-TGGACTCTGGTGATGGTGTC-3' } \\
\text { 5'-CCTCCAATCCAAACACTGTA-3' }\end{array}$ & 60 & U60489 \\
\hline
\end{tabular}


Fusarium oxysporum were cultured in the center of a 100 $\mathrm{mm}$ diameter Petri dish containing PDA at $25^{\circ} \mathrm{C}$ to obtain colonized mycelia. After 6 hours, three paper disks $(8 \mathrm{~mm}$ diameter) were placed $1 \mathrm{~cm}$ away from the edge of the petri dish and $30 \mu \mathrm{l}$ of the Bacillus sp. JS and DH5 $\alpha$ suspension were added to each paper disk. One paper disk was kept as an untreated control. The plates were incubated under a $12 \mathrm{~h}$ light/dark cycle at $25^{\circ} \mathrm{C}$ for 1 week, until the mycelia grew outwards to the rim of the Petri dish.

To assess disease resistance, the tobacco fungal pathogen, $R$. solani AG-1 (IB) KACC No. 40110 and P. nicotianae KACC No. 40906 was grown on PDA and V8 juice agar (200 ml V8 juice, $15 \mathrm{~g}$ agar, $1.5 \mathrm{~g} \mathrm{CaCO}_{3}$ in 11 distilled water) respectively. Two month old Nicotiana tabacum 'Xanthi' and six Petri dishes containing half-strength MS medium (Duchefa, Netherland) and Bacillus sp. JS culture were placed in a $36 \mathrm{~L}$ plastic container. Petri dishes containing Half-strength MS medium without JS used as control. The plastic container was placed in a growth room maintained at $26^{\circ} \mathrm{C}$ and $16 \mathrm{~h}$ light $/ 8 \mathrm{~h}$ dark light condition. After 4 days, a 3-mm diameter plug of medium containing the fungal mycelia was placed on the adaxial leaf surface. The disease severity was evaluated based on lesion size 3 days after inoculation. Each experiment was performed twice with three replicates per treatment.

Complementary DNA of the tobacco plant was prepared as follows: Sterilized tobacco (N. tabacum 'Xanthi') seeds were sown on one side of divided Petri dishes $(100 \times 15$ $\mathrm{mm}$ ) containing half strength MS medium with $1.5 \%$ sucrose. Eighteen days later, $70 \mu \mathrm{l}$ of Bacillus sp. JS culture was dropped on the other side of the divided Petri dish, which was sealed with sealing wrap. Plant sample was obtained 24, 48, 72 and $96 \mathrm{~h}$ later from the treatment. Total RNA of tobacco seedlings was extracted using the modified CTAB method (Kim and Hamada, 2005) and treated with DNase I (Takara Bio, Japan) to remove contaminated genomic DNA. First-strand cDNA was synthesized from $1 \mu \mathrm{g}$ of total RNA using PrimeScript First Strand cDNA Synthesis Kit (Takara Bio, Japan) and oligo dT primer. The synthesized cDNA was diluted with 10 volume of distilled water. PCR amplification was conducted with $2 \mu \mathrm{l}$ of diluted cDNA, $5 \mu \mathrm{l}$ of $10 \times$ buffer, $4 \mu \mathrm{l}$ of $2.5 \mathrm{mM}$ dNTPs, $1 \mu \mathrm{l}$ of $10 \mu \mathrm{M}$ primers, and $2 \mathrm{U}$ of Taq DNA polymerase (Takara Bio, Japan) in a total volume of $50 \mu$. The PCR reaction consisted of pre-denaturation at $94^{\circ} \mathrm{C}$ for $3 \mathrm{~min}, 32$ or 35 cycles of amplification comprised of denaturation for $30 \mathrm{~s}$ at $94^{\circ} \mathrm{C}$, annealing for $30 \mathrm{~s}$ at $50^{\circ} \mathrm{C}$ or $60^{\circ} \mathrm{C}$, extension for $1 \mathrm{~min}$ at $72^{\circ} \mathrm{C}$, followed by a final extension at $72^{\circ} \mathrm{C}$ for 5 min. The amplified PCR products were fractionated using $1.2 \%$ agarose gel electrophoresis. All gene-specific primers used in this study were designed as described by Kim et al. (2008) in Table 1.

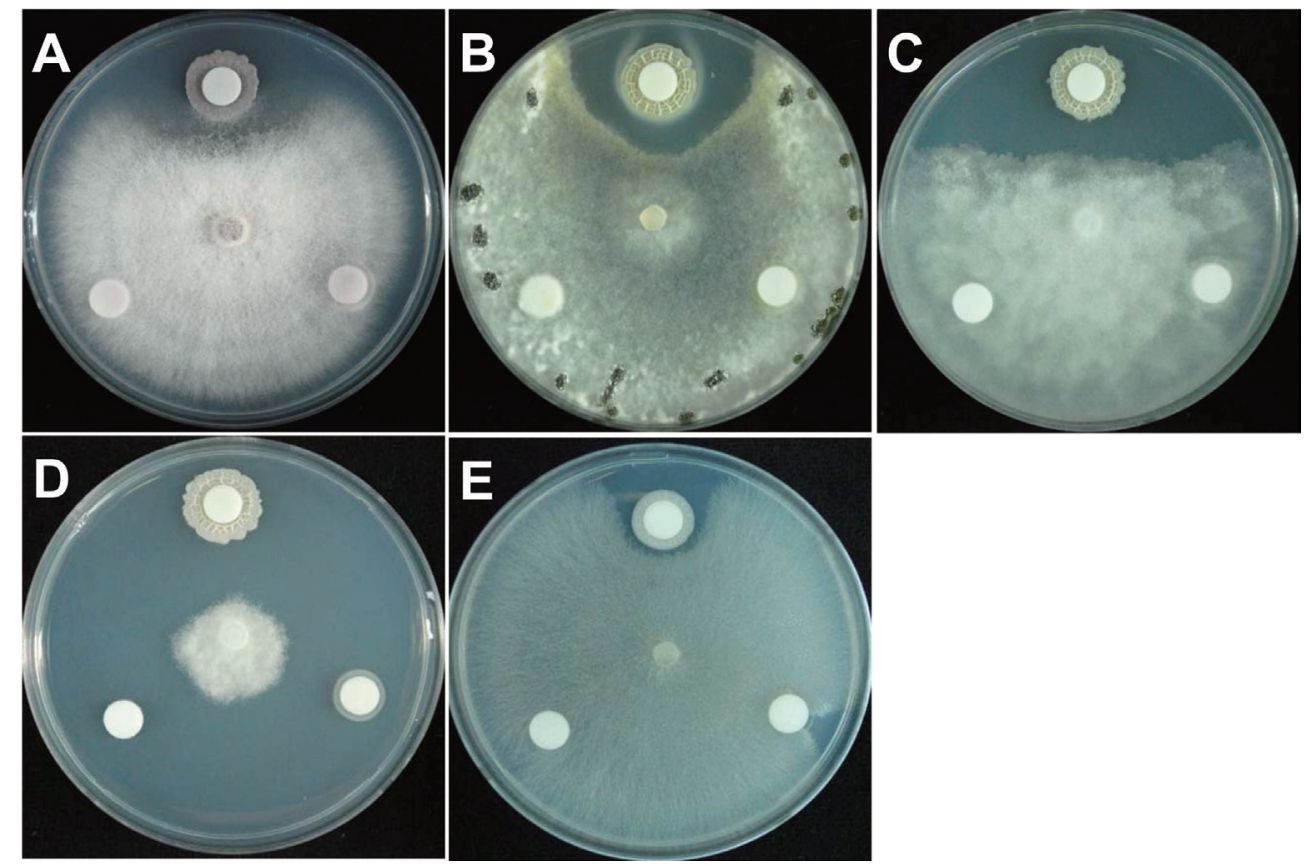

Fig. 1. In vitro antifungal activity of Bacillus subtilis JS. Inhibition of mycelial growth of Fusarium oxysporum (A), Sclerotinia sclerotiorum (B), Phytophthora capsici (C) and Phytophthora nicotianae KACC No. 40906 (D). Rhizoctonia solani AG-1 (IB) KACC No. 40110 (E). Treatments were as follows: Bacillus subtilis strain JS (upper), untreated (lower left), DH5a (lower right). 
Bacillus sp. JS was isolated from the soil of a Miscanthus growing pot in a greenhouse at the University of Seoul. Genome sequence analysis revealed that the genome of $\mathrm{Ba}$ cillus sp. JS had $95.31 \%$ identity to those of B. subtilis 168 and BSn5 in average nucleotide identity based on BLAST (ANIb) (Song et al., 2012).

Five soil-borne fungal pathogens $-R$. solani AG-1 (IB) KACC No. 40110, P. nicotianae KACC No. 40906, $S$. sclerotiorum, $P$. capsici, and F. oxysporum - were employed to determine the antifungal activity of Bacillus sp. JS. In vitro, Bacillus sp. JS presented significant inhibitory activity against the mycelial growth of all fungal pathogens tested (Fig. 1). An inhibition zone was not observed around the untreated and DH5 $\alpha$ paper disks. To distinguish between the fungistasis and fungicidal actions of Bacillus sp. JS, the mycelial block at the edge of the colony was transferred to new medium. Mycelial growth of $P$. capsici, $P$. nicotianae KACC No. 40906, and S. sclerotiorum did not recover, whereas those of $R$. solani AG-1 (IB) KACC No. 40110 and $F$. oxysporum resumed (data not shown). These results implicated that secreted material by Bacillus sp. JS have fungicidal actions to $P$. capsici, $P$. nicotianae KACC No. 40906, and S. sclerotiorum and fungistasis to R. solani AG-1 (IB) KACC No. 40110 and F. oxysporum.

The rhizosphere of plants is the habitat of many diverse organisms like fungi and bacteria (Whipps, 2001). Some soil bacteria may act as antagonists against fungal pathogens by secreting antifungal metabolites that directly inhibit fungal growth or indirectly promote plant growth (Moyne et al., 2004; Vespermann et al., 2007). Bacillus sp. JS has putative genes that encode nonribosomal peptide synthetases, polyketide synthases, and bacteriocin-biosynthetic enzymes as antibiotic-related genes (Song et al., 2012). These results support the idea that Bacillus sp. JS has potential as a biocontrol agent through its production of antibiotic compounds that inhibit fungal growth.

To determine whether volatiles of Bacillus sp. JS confer disease resistance to the tobacco plant, $P$. nicotianae, the causal agent of black shank and $R$. solani, the causal agent of target spot in tobacco were inoculated to the leaf surface

A

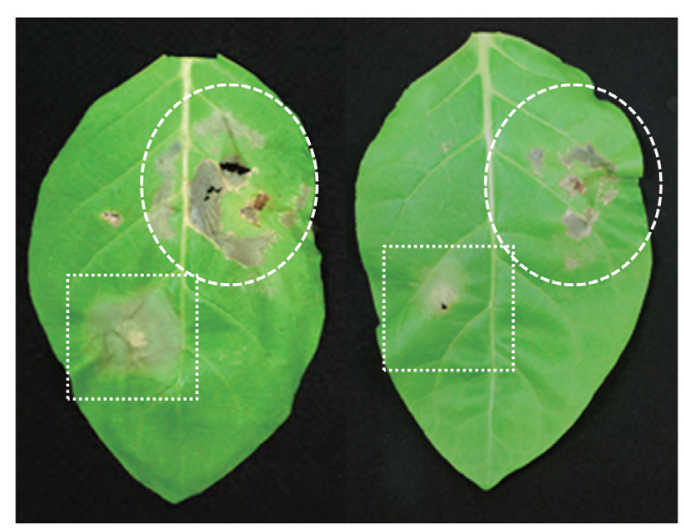

B

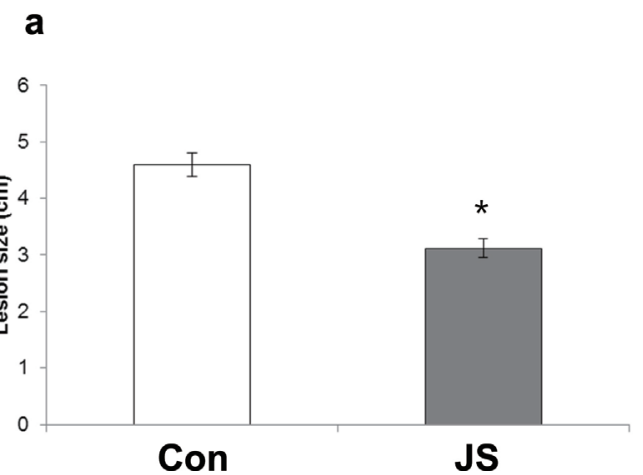

JS

b

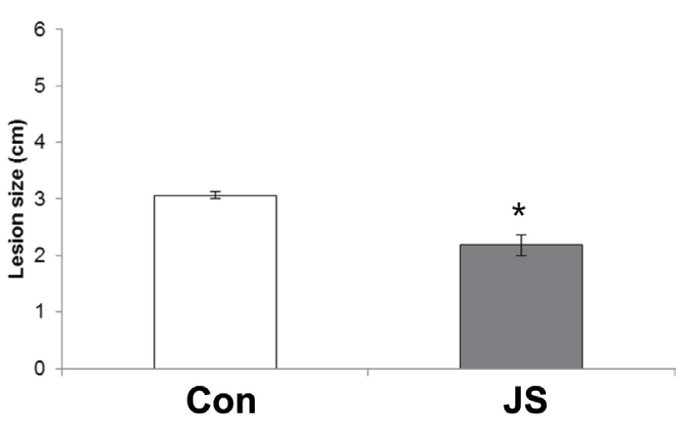

Fig. 2. Enhanced disease resistance in tobacco leaves treated with volatiles of B. subtilis JS. Symptom on tobacco leaf by Rhizocronia solani AG-1 (IB) (dotted circle) Phytophthora nicotianae (dotted square) (A). Left shows control treatment (Con) and Right shows Bacillus subtilis strain JS treatment (JS). Half-strength MS medium used as a control. Disease evaluation involved determination of the lesion diameter 3 days after Rhizoctonia solani AG-1 (IB) (a) Phytophthora nicotianae (b) inoculation (B). Each data point represents the mean \pm standard error $(\mathrm{n}=7)$. The asterisk indicate significant difference according to the Independent Samples t-Test at $P=0.05$. 
of two month old tobacco plants.

In both the $P$. nicotianae and $R$. solani inoculation tests, lesions on the leaves of tobacco plants treated with volatiles of Bacillus sp. JS were smaller than those of untreated tobacco (Fig. 2A) and about 30\% smaller than those of control leaves in lesion diameter (Fig. 2B). Tobacco plants treated with Bacillus sp. JS showed significantly higher resistance against $P$. nicotianae and $R$. solani, although their responses to the two pathogens were not comparatively assessed. Because resistance inducing bacteria and challenging pathogens remained spatially separated throughout the experiment, disease resistance in tobacco plants by direct antagonism of the Bacillus sp. JS to the pathogen could be ruled out. However, it is reasonable to assume that the resistance induced by the volatiles of Bacillus sp. JS could be plant-mediated.

In the last several decades, researchers have conferred systemic resistance against pathogens to decrease disease severity. The studies have shown that plants can obtain systemic resistance by exposure to certain strains of PGPR, which is termed ISR (Raupach et al., 1996; Ryu et al., 2004; Whipps, 2001). To presently ascertain whether PGPR affects the expression levels of a series of $P R$ genes for ISR, expression of several genes was monitored by RTPCR. $P R$ gene expression pattern according to exposure time was characterized by quantitative RT-PCR (Fig. 3). The expression levels of acidic and basic $P R-2(\beta-1,3-$ glucanase) increased after $96 \mathrm{~h}$ of exposure. Acidic $P R-3$ ( $P R-P$ and $P R-Q$, chitinase) as well as acidic and basic $P R-4$ (chitinase) were also up-regulated. While expression of $P R-P$ was increased after $72 \mathrm{~h}$, expression of $P R-Q$ increased more rapidly after $24 \mathrm{~h}$. Acidic and basic $P R-4$ were up-regulated and their expression levels gradually increased with time. $\beta$-1,3-glucanase and chitinase are PR proteins that are notably expressed during the plant resistance response against pathogens (Van Loon et al., 2006). Since the cell walls of many fungi are composed of $\beta-1,3$ glucan and chitin (Adams, 2004), $\beta$-1,3-glucanase and chitinase seem capable of attacking the cell wall of fungal pathogens. They also have the ability to degrade the fungal cell wall and inhibit mycerial growth (Mauch et al., 1988). Increased expression of $\beta$-1,3-glucanase $(P R-2)$ and chitinase gene $(P R-3)$ may contribute to enhanced resistance against fungal pathogens. Expression of acidic $P R-9$ also increased gradually with time. $P R-9$ encodes lignin forming peroxidase, which can assist in lignification of the plant cell wall in response to pathogen attack by serving as a physical barrier to enhance resistance (Lagrimini et al., 1987; Passardi et al., 2004). Basic PR-14 (lipid transfer protein) also showed increased expression after $72 \mathrm{~h}$. Lipid transfer proteins (PR-14) have been implicated in antifungal and antibacterial activities and accumulate at the tissue surface at much higher concentrations than required level to inhibit pathogen growth in vitro (Kader, 1996).

Although PR protein may be detectable in healthy tissues at basal levels or induced by various stimuli and in various developmental stages, the protein is induced by pathogen attack. It exhibits in vitro antimicrobial activities and accumulates in the plant during the plant resistance response (Sels et al., 2008). Kim et al. (2008) also reported that sweet potato swpa4 peroxidase over expressing tobacco plants showed increased expression of acidic PR-2, acidic PR-3 (PR-P and PR-Q), acidic PR-4, and acidic PR-9, resulting in disease resistance to the fungal pathogen, $P$. nicotianae. In our experiments, tobacco plants exposed to volatiles of $B$. subtilis also showed significant resistance against $P$. nicotianae and $R$. solani (Fig. 2). These results suggest that exposure of tobacco plants to volatiles of Bacillus sp. may result in activation of a signal transduction pathway that is directly or indirectly related to pathogen disease resistance. Moreover, $P R-1$ genes were not expressed by volatiles of Bacillus sp. JS. The $P R-1$ gene is most consistently used as an indicator of SAR (van Loon and van Strien, 1999). This indicates that disease resistance induced by Bacillus sp. JS volatiles may be controlled by a SA-independent signaling pathway, unlike SAR.

PGPR may also activate defense pathways in response to pathogens, since up-regulation of $\beta$-1,3-glucanase and chitinase was detected. $\beta$-1,3-glucanase and chitinase can

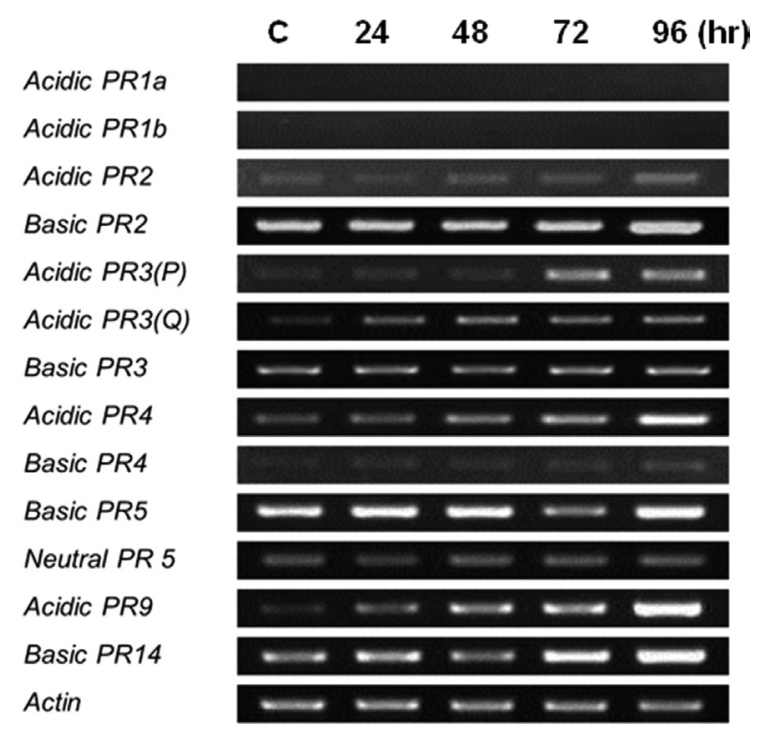

Fig. 3. Analysis of PR genes expression levels by RT-PCR. Plants were harvested after 24, 48, 72, and $96 \mathrm{~h}$ exposure to volatiles of Bacillus subtilis strain JS treatment. Actin was included as a constitutive control, C: untreated control. 
indirectly induce the release of oligosaccharides that can act as elicitors to activate plant defense responses (Shibuya and Minami, 2001). It may be that volatile emission can also contribute to defense responses through the resistance mechanisms induced by $\beta$-1,3-glucanase and chitinase. However, regardless of whether $\beta$-1,3-glucanase and chitinase are present in plants or not, other direct or indirect defenses by PGPR are worthy of further study.

In conclusion, physical damage of infection sites by fungal pathogens was less severe in leaves pre-treated with volatiles of Bacillus sp. JS compared to control leaves. Development of leaf holes caused by physical damage were also delayed (Fig. 2A). These results may indicate that the growth of fungal pathogens was delayed in planta by treatment with volatiles of Bacillus sp. JS. Gene expression analysis showed that these volatiles induced increased expression of PR genes involved in fungal cell wall degradation and plant cell wall strengthening (Fig. 3). The observation of smaller lesion sizes in the leaves treated with the volatiles may be due to increased expression of $P R$ genes, which is characterized as ISR.

Whether the signaling pathways regulating Bacillus sp. JS-mediated ISR and pathogen-induced SAR converge to elicit a similar or partially similar phenotypic effect remains to be determined. It is possible that certain defenserelated activities are responsible for enhancing resistance. PR gene expression might further enhance resistance through the activity of PR proteins (Sels et al., 2008; van Loon et al., 2006). SAR and the observed PGPR-mediated ISR may share part of the signal transduction pathway(s) controlling systemic resistance. Alternatively, Bacillus sp. JS could trigger a completely different, parallel pathway unconnected with the accumulation of SA or the activation of $P R-1$ genes. Further study of the Bacillus sp. JS will provide important information for SA independent defense signaling pathway represented as ISR.

\section{Acknowledgments}

This work was supported by a grant (Code \# S211214L030210) from Forest Science \& Technology Projects, Forest Service and by Advanced Production Technology Development Program, Ministry of Agriculture, Food and Rural Affairs (Code \# 1100345), Republic of Korea.

\section{References}

Adams, D. J. 2004. Fungal cell wall chitinases and glucanases. Microbiology 150:2029-2035.

Agrios, G. N. 2005. Plant Pathology, 5th edn. Elsevier Academic
Press, Oxford UK.

Defago, G. 1993. 2,4-Diacetylphloroglucinol, a promising compound in biocontrol. Plant Pathol. 42:311-312.

Duijff, B. J., Bakker, P. A. H. M. and Schippers, B. 1994. Suppression of fusarium wilt of carnation by Pseudomonas putida WCS358 at different levels of disease incidence and iron availability. Biocontrol Sci. Technol. 4:279-88.

Haas, D. and Défago, G. 2005. Biological control of soil-borne pathogens by fluorescent pseudomonads. Nat. Rev. Microbiol. 3:307-319.

Kim, S.-H. and Hamada, T. 2005. Rapid and reliable method of extracting DNA and RNA from sweetpotato, Ipomoea batatas (L.) Lam. Biotech. Lett. 27:1841-1845.

Kader, J. C. 1996. Lipid transfer proteins in plants. Annu. Rev. Plant Physiol. Plant Mol. Biol. 47:627-654.

Kim, Y.-H., Kim, C. Y., Song, W.-K., Park, D.-S., Kwon, S.-Y., Lee, H.-S., Bang, J.-W. and Kwak, S.-S. 2008. Overexpression of sweetpotato swpa4 peroxidase results in increased hydrogen peroxide production and enhances stress tolerance in tobacco. Planta 227:867-881.

Lagrimini, L. M., Burkhart, W., Moyer, M. and Rothstein, S. 1987. Molecular cloning of complementary DNA encoding the lignin-forming peroxidase from tobacco: Molecular analysis and tissue-specific expression. Proc. Natl. Acad. Sci. USA 84:7542-7546.

Ligon, J. M., Hill, D. S., Hammer, P. E., Torkewitz, N. R., Hofmann, D., Kempf, H. J. and Van Pee, K. H. 2000. Natural products with antifungal activity from Pseudomonas biocontrol bacteria. Pest Manag. Sci. 56:688-695.

Mauch, F., Mauch-Mani, B. and Boller, T. 1988. Antifungal hydrolases in pea tissue : II. Inhibition of fungal growth by combinations of chitinase and beta-1,3-glucanase. Plant Physiol. 88:936-942.

Moyne, A. L., Cleveland, T. E. and Tuzun, S. 2004. Molecular characterization and analysis of the operon encoding the antifungal lipopeptide bacillomycin D. FEMS Microbiol. Lett. 234:43-49.

Nielsen, T. H., Sørensen, D., Tobiasen, C., Andersen, J. B., Cristophersen, C., Givskov, M. and Sørensen, J. 2002. Antibiotic and biosurfactant properties of cyclic lipopeptides produced by fluorescent Pseudomonas spp. from the sugar beet rhizophere. Appl. Environ. Microbiol. 68:3416-3423.

Park, K. S. and Kloepper, J. W. 2000. Activation of PR-1a promoter by rhizobacteria which induce systemic resistance in tobacco against Pseudomonas syringae pv. tabaci. Biol. Control 18:2-9.

Passardi, F., Penel, C. and Dunand, C. 2004. Performing the paradoxical: how plant peroxidases modify the cell wall. Trends Plant Sci. 9:534-540.

Pieterse, C. M. J , Van Wees, S. C. M., Van Pelt, J. A., Knoester, M., Laan, R., Gerrits, H., Weisbeek, P. J. and Van Loon, L. C. 1998. A novel signaling pathway controlling induced systemic resistance in Arabidopsis. Plant Cell 10:1571-1580.

Raaijmakers, J. M., Vlami, M. and De Souza, J. T. 2002. Antibi- 
otic production by bacterial biocontrol agents. Antonie van Leeuwenhoek 81:537-547.

Raupach, G. S., Liu, L., Murphy, J. F., Tuzun, S. and Kloepper, J. W. 1996. Induced systemic resistance in cucumber and tomato against cucumber mosaic cucumovirus using plant growthpromoting rhizobacteria (PGPR). Plant Dis. 80:891-894.

Ryals, J. A., Neuenschwander, U. H., Willits, M. G., Molina, A., Steiner, H. Y. and Hunt, M. D. 1996. Systemic acquired resistance. Plant Cell 8:1809-1819.

Ryu, C.-M., Farag, M. A., Hu, C. H., Reddy, M. S., Kloepper, J. W. and Pare, P. W. 2004. Bacterial volatiles induce systemic resistance in Arabidopsis. Plant Physiol. 134:1017-1026.

Sels, J., Mathys, J. De Coninck, B. M., Cammue, B. P. and De Bolle, M. F. 2008. Plant pathogenesis-related (PR) proteins: a focus on PR peptides. Plant Physiol. Biochem. 46:941-950.

Sharifi-Tehrani, A., Zala, M., Natsch, A., Moenne-Loccoz, Y. and Defago, G. 1998. Biocontrol of soil-borne fungal plant diseases by 2,4-diacetylphloroglucinol-producing fluorescent pseudomonads with different restriction profiles of amplified 16S rDNA. Eur. J. Plant Pathol. 104:631-643.

Shibuya, N. and Minami, E. 2001. Oligosaccharide signalling for defence responses in plant. Physiol. Mol. Plant Pathol. 59:
223-233.

Song, J. Y., Kim, H. A., Kim, J.-S., Kim, S.-Y., Jeong, H., Kang, S. G., Kim, B. K., Kwon, S.-K., Lee, C. H., Yu, D. S., Kim, B. K., Kim, S.-H., Kwon, S. Y. and Kim, J. F 2012. Genome sequence of the plant growth-promoting rhizobacterium $\mathrm{Ba}$ cillus sp. strain JS. J. Bacteriol. 194:3760-3761.

Van Loon, L. C., Rep, M. and Pieterse, C. M. 2006. Significance of inducible defense related proteins in infected plants. Аnпu. Rev. Phytopathol. 44:135-162.

Van Loon, L. C. and Van Strien, E. A. 1999. The families of pathogenesis-related proteins, their activities, and comparative analysis of PR-1 type proteins. Physiol. Mol. Plant Pathol. 55:85-97.

Vespermann, A., Kai, M. and Piechulla, B. 2007. Rhizobacterial Volatiles Affect the Growth of Fungi and Arabidopsis thaliana. Appl. Environ. Microbiol. 73:5639-5641.

Yedidia, I., Benhamou, N. and Chet, I. 1999. Induction of defense responses in cucumber plants (Cucumis sativus L.) by the biocontrol agent Trichoderma harzianum. Appl. Environ. Microbiol. 65:1061-1070.

Whipps, J. M. 2001. Microbial interactions and biocontrol in the rhizosphere. J. Exp. Bot. 52:487-511. 